\title{
The role of corticosteroids in bronchiolitis and croup
}

\author{
Anthony D Milner
}

The introduction of systemic and inhaled topical corticosteroids may not have significantly reduced mortality from childhood asthma, but it has greatly improved the quality of life for many children and now they have an important and well established role in asthma management. Over the years corticosteroids have also been considered as possible treatment for two other forms of airway obstruction - acute laryngobronchitis (or croup) and acute bronchiolitis.

The effects of corticosteroids on croup have been so dramatic and well documented that the only surprise is that this form of treatment has taken so long to be generally accepted. In $1980^{1}$ a critical assessment of nine studies on the efficacy of systemic corticosteroids was published. Most were considered to have unsatisfactory clinical designs and it was concluded that the role of corticosteroids in the treatment of croup was unproven. The turning point came in 1989 with the publication by Kairys and colleagues ${ }^{2}$ of a meta-analysis of nine placebo controlled trials considered to be satisfactory. Of these, only two of seven showed a significant advantage for systemic corticosteroids after 12 hours of treatment and two of four at 24 hours. One of the four studies in which children required intubation showed significant protection. Although most of the studies failed to show significant effects, in all the studies there was a trend in favour of corticosteroids so that the metaanalysis demonstrated a positive effect. The authors claimed that their data supported the use of steroids in infants ill enough to be admitted to hospital. This led to renewed interest in this area.

At one extreme of severity, oral prednisolone has been shown by the Perth group ${ }^{3}$ to reduce the time to extubation from a mean of 138 hours to 98 hours, and also the need for reintubation. A further study ${ }^{4}$ found that a relatively small dose of dexamethasone, $0.15 \mathrm{mg} / \mathrm{kg}$, was as effective as $0.6 \mathrm{mg} / \mathrm{kg}$ in relieving symptoms and reducing the time to discharge. Others ${ }^{5}$ have compared the effects of corticosteroids with nebulised adrenaline and there are now two randomised studies on the outpatient use of oral corticosteroids, on ${ }^{6}$ showing that treatment reduces the need for reattendance at the emergency department and the other ${ }^{7}$ indicating a more rapid resolution in respiratory symptoms.

There has also been increasing interest in the role of inhaled nebulised budesonide in the treatment of croup. Three placebo controlled trials have been published, ${ }^{8-10}$ all of which showed more rapid resolution in symptoms, and two reported a reduction in time to discharge. One study ${ }^{11}$ has compared nebulised budesonide with oral dexamethasone in a dose of $0.6 \mathrm{mg} / \mathrm{kg}$. Both treatments were superior to placebo with non-significant trends in favour of dexamethasone. A further publication ${ }^{12}$ in which all the children received oral corticosteroids and were then randomised to receive either budesonide or placebo inhalations showed a reduction in symptoms after four hours in the treatment group but no difference in hospital admission rates.

These studies confirm that both systemic steroids and nebulised budesonide are effective therapies. As stated recently by Thomson, ${ }^{13}$ croup is usually benign and selflimiting so that treatment should be reserved for those with stridor and recession at rest. Oral corticosteroids would appear to be preferable as administration is less invasive in a distressed young child and budesonide at $£ 4.46$ for $2 \mathrm{mg}$ is approximately 100 times more expensive than oral dexamethasone.

For acute bronchiolitis, which is caused by respiratory syncytial virus (RSV), it is well established that the disease involves an acute inflammatory process with massive invasion of the respiratory tract by neutrophils. ${ }^{14}$ It is also generally accepted that bronchiolitis is associated with a risk factor of 3-4 for subsequent asthma symptoms, although it remains contentious whether the bronchiolitis itself is responsible $^{1516}$ or whether those at increased risk for developing severe bronchiolitis, either from a genetic atopy tendency or subnormal neonatal lung function, ${ }^{17}$ are selectively admitted to hospital. Whatever the mechanism, bronchiolitis would appear to be a condition that is likely to be modified by corticosteroid therapy. It has always been something of a surprise that in the past, with one exception, ${ }^{18}$ no double blind controlled study has shown measurable benefit. The initial positive study published by Oski and colleagues in abstract form ${ }^{18}$ was relatively small, involving only 20 infants. Of these, nine received dexamethasone and 11 placebo. The results, however, were quite striking with a significant reduction in the time on oxygen (25 versus 44 hours) and more rapid discharge from hospital (4.4 versus 7.0 days). Subsequent studies with larger numbers of infants - for example, Sussman et $a l^{19}$ (49 infants), Dabbous et $a l^{20}$ (44 infants), Connolly et $a l^{21}$ (95 infants), and the large study by Leer et $a l^{22}$ (297) - all failed to show that systemic corticosteroids had any effect on the natural history of acute bronchiolitis. Even Oski et al were unable to confirm their initial findings in a subsequent larger study. ${ }^{23}$ As a result of these publications, the Committee on Drugs for the American Academy of Pediatrics concluded in 1970 that "there is no scientific basis for the routine administration of corticosteroids in bronchiolitis". ${ }^{23}$

Perhaps because of this statement, there were relatively few studies in the next 20 years and the consensus remained that systemic steroids had little to offer in the management of bronchiolitis. One study ${ }^{24}$ on the effects of steroids and $\beta_{2}$ agonists on the symptoms of 32 wheezy infants, some of whom (number not stated) had bronchiolitis, suggested that neither form of treatment had any effect on the rate of resolution of symptoms but that the combination was useful. The design of the study was relatively complicated with only eight infants in each treatment cell. Subsequent studies by De Boeck et $a l^{25}$ and Springer et $a l^{26}$ (50 infants) were also negative. Perhaps the strongest statement against the use of systemic steroids has been provided by a study from Chicago published in the Lancet last year. ${ }^{27}$ This group recruited 118 infants under the age of 12 months who required admission to hospital for acute bronchiolitis. Sixty five received intramuscular dexamethasone $(1 \mathrm{mg} / \mathrm{kg}$ daily for up to three days) and 53 were given saline injections as placebo. They were unable to show any effects of steroid therapy on the rate of resolution of symptoms, time in oxygen, or the incidence of respiratory symptoms in the 10-14 days after discharge.

In total contrast, in this issue of Thorax van Woensel et $a l^{28}$ report the results of a well designed study into the effects of oral prednisolone on respiratory symptoms in 
infants admitted to the Beatrix Children's Hospital in Groningen with acute RSV bronchiolitis. All were under 24 months of age (mean 3.6 months). Twenty seven received prednisolone $(1 \mathrm{mg} / \mathrm{kg} / \mathrm{day})$ and the remaining 27 received placebo. Analysis of the results showed that prednisolone reduced the time on mechanical ventilation from a mean of 6.3 to 5.6 days in the 14 infants requiring ventilatory support. Although this was not significant, the time in hospital was also reduced from a mean 17.0 to 11.0 days $(p<0.001)$. In the 40 infants with less severe bronchiolitis, prednisolone therapy was associated with more rapid resolution of symptoms over the first three days, an effect which was significant, but the time in hospital was only reduced by one day ( 7.3 versus 8.3 days). When the analysis was restricted to the 13 infants with high initial symptom scores (seven on prednisolone and six on placebo) the differences in the rate of recovery were more marked $(p<0.02)$ but the time in hospital remained similar $(7.7$ versus 8.0 days). The authors, who appear to be unaware of the Chicago study, ${ }^{27}$ suggest that their study has been almost uniquely positive because others have either failed to recruit only those with bronchiolitis or have excluded infants with more severe illness - that is, those in whom they had the most success. However, the first of these criticisms can be aimed at their own data. The inclusion requirement was that all should be RSV positive on immunofluorescence, have acute tachypnoea, wheezing, and/or reduced breath sounds, cyanosis, and the use of accessory muscles. This will inevitably include infants presenting with asthma. This supposition is supported by a relatively high incidence of family history of atopy (35\%). This is not defined but presumably is limited to first degree relatives. Our own experience ${ }^{16}$ and that of others ${ }^{15}$ indicates that, if the diagnosis of bronchiolitis is limited to those with fine crepitations ${ }^{29}$ rather than wheeze, the relationship between atopy and bronchiolitis disappears. Interestingly, the largest negative study (by Leer et $a l^{22}$ ) included the presence of crepitations in the inclusion criteria. Even despite this, the findings are surprising as three previous studies have failed to show any benefit from systemic corticosteroids in even asthmatic infants under the age of one year. ${ }^{243031}$ One possible explanation is that there is a type 1 error due to the sample size. Against this is the finding of positive responses in both the ventilated and non-ventilated subgroups. Obviously a large multicentre study will now need to be planned to resolve this controversy.

There has also been interest in the possible role of inhaled steroids in both the acute attack and in the prevention of post-bronchiolitic asthma symptoms. There is one claim ${ }^{32}$ that high dose nebulised budesonide not only leads to more rapid discharge from hospital but also reduces the incidence of subsequent wheezing episodes, the need to visit the general practitioner, and admission to hospital for further respiratory problems. The data are, however, of limited value as historical controls were used. A subsequent double blind study on 40 infants admitted to hospital with acute bronchiolitis failed to confirm any of these claims ( $P$ Seddon, personal communication).

A paper from Oslo ${ }^{33}$ showed that an eight week course of inhaled beclomethasone given to infants reduced postbronchiolitis respiratory problems when given some months after the acute attack. Since this publication, there has been interest in the possible prophylactic effect of a course of inhaled steroids given as soon as the infant is discharged home. One such study ${ }^{34}$ involving 100 infants found that both inhaled nebulised sodium cromoglycate and budesonide reduced the incidence of wheeze over the subsequent 16 weeks, and budesonide also reduced the need for further hospital admission over the next 16 weeks compared with placebo. Again, wheezing alone was used as the diagnostic criterion and $39 \%$ had a first degree history of atopy. However, the improvements on active treatment totally disappeared for sodium cromoglycate when the atopic infants were removed and were no longer significant for inhaled budesonide. There are at least two other double blind studies which have failed to show any prophylactic benefit (G Fox, personal communication; P Seddon, personal communication).

Thus it appears that, in the case of croup (acute laryngobronchitis), corticosteroids given systemically or by inhalation are useful in the management of those children who require admission to hospital. For acute bronchiolitis, however, for the reasons outlined above the role of these drugs remains less certain. Inhaled corticosteroids are helpful in the management of post-bronchiolitic asthma symptoms but further positive studies are needed before prophylactic courses can be recommended for use immediately after acute bronchiolitis.

Department of Paediatrics,

A D MILNER

United Medical and Dental School,

St Thomas' Hospital,

London SEI 7EH, UK

1 Tunnessen W, Feinstein A. The steroid-croup controversy: an analytic review of methodologic problems. $\mathcal{F}$ Pediatr 1980;34:751.

2 Kairys SW, Olmstead EM, O'Connor GT. Steroid treatment of laryngotracheitis: a meta-analysis of the evidence from randomized trials. Pediatrics 1989;83:683-93.

3 Tibals J, Shann F, Landau L. Placebo-controlled trial of prednisolone in children intubated for croup. Lancet 1992;340:745-8.

4 Geelhoed GC, Macdonald WBG. Oral dexamethasone in the treatment of croup. Pediatrics 1996;97:463.

5 Kuusela A, Vesikari T. A randomised double-blind, placebo-controlled trial of dexamethasone and racemic adrenaline in the treatment of croup. Acto Paediatr Scand 1988;7:99-104.

6 Geelhoed GC, Turner J, Macdonald WBG. Efficacy of a small single dose of oral dexamethasone for out-patient croup: a double-blind placebo of oral dexamethasone for out-patient
controlled trial. $B M \mp 1996 ; 313: 140-2$.

7 Cruz MN, Steward G, Rosenberg N. Use of dexamethasone in the outpatient management of acute laryngotracheitis. Pediatrics 1995;96:220-3.

8 Husby S, Agertoff L, Mortenson S, Pedersen S. Treatment of croup with nebulised steroid (budesonide): a double blind, placebo controlled study. Arch Dis Child 1993;68:352-5.

9 Klassen TP, Feldman ME, Watters LK, Sutcliffe T, Rowe PC. Nebulised budesonide for children with mild-moderate croup. N Engl $\mathscr{F}$ Med 1994; 331:285-9.

10 Godden CW, Campbell MJ, Hussey M, Cogswell JJ. Double blind placebo controlled trial of nebulised budesonide for croup. Arch Dis Child 1997, 76:155-7.

11 Geelhoed GC, Macdonald WBG. Oral and inhaled steroids in croup: a randomised placebo-controlled trial. Pediatr Pulmonol 1995;20:355-61.

12 Klassen TP, Watters LK, Feldman ME, Sutcliffe T, Rowe PC. The efficacy of nebulised budesonide in dexamethasone-treated outpatients with croup. Pediatrics 1996;97:463-6.

13 Thomson A. Double blind placebo controlled trial of nebulised budesonide for croup: commentary. Arch Dis Child 1997;76:157-8.

14 Everard ML, Swarbrick A, Wrightham M, McIntyre J, Dunkley C, James $\mathrm{PD}$, et al. Analysis of cells obtained by bronchial lavage of infants with PD, et al. Analysis of cells obtained by bronchial lavage of infants
respiratory syncytial virus infection. Arch Dis Child 1994;71:428-32.

15 Pullan CR, Hey EN. Wheezing, asthma and pulmonary dysfunction 10 years after infection with respiratory syncytial virus in infancy. $B M \mathcal{F} 1982$ 284:1665-9.

16 Murray M, Webb MS, O'Callaghan C, Swarbrick AS, Milner AD. Respiratory status and allergy after bronchiolitis. Arch Dis Child 1992;67: $482-7$.

17 Young S, O'Keeffe PT, Arnott J, Landau L. Lung function and airways responsiveness and respiratory symptoms before and after bronchiolitis. Arch Dis Child 1995;72:16-24.

18 Oski FA, Salitsky S, Barness LA. Steroid therapy in bronchiolitis: a doubleblind study. Am f Dis Child 1961;102:759.

19 Sussman S, Grossman M, Magofinn R, Shielbe J. Dexamethasone in obstructive respiratory tract infection in children. A controlled study. Pediatrics 1964;34:851.

20 Dabbous IA, Tkachyk JS, Stamm SJ. A double blind study on the effects of corticosteroids in the treatment of bronchiolitis. Pediatrics 1966;37: $477-84$.

21 Connolly JH, Field CMB, Glasgow JTF, Slatter CM, MacLynn DM. A double blind trial of prednisolone in epidemic bronchiolitis due to respiratory syncytial virus. Acta Paediatr Scand 1969;58:116-20.

22 Leer JA, Green JL, Heimlich EM, Hyde JS, Moffet HL, Young GA, et Leer JA, Green JL, Heimlich EM, Hyde JS, Moffet HL, Young GA, $e t$.
alticosteroid treatment in bronchiolitis. Am f Dis Child 1969;117: 495-503.

23 Yaffe SE, Weiss CF. Committee on Drugs, American Academic of Pediatrics. Should steroids be used in treating bronchiolitis? Pediatrics 1970;46:640-2

24 Tal A, Bavilski C, Yohai D, Bearman JE, Gorodischer R, Moses SW. Dexamethasone and salbutamol in the treatment of acute wheezing in infants. Pediatrics 1983;71:13-18.

25 De Boeck K, Van der Aa N, Van Lierde S, Corbeel L, Eeckels R. Respiratory syncytial virus bronchiolitis. A double blind dexamethasone efficacy study. Am ₹ Respir Crit Care Med 1994;149:A345. 
26 Springer C, Bar-Yishay E, Uwayyed K, Avital A, Vilozni D, Godfrey S. Corticosteroids do not affect the clinical or physiological status of infants with bronchiolitis. Pediatr Pulmonol 1990;9:181-5.

27 Roosevelt G, Sheenan K, Grupp-Phelan J, Tanz RR, Listernick R. Dexamethasone in bronchiolitis: a randomised controlled trial. Lancet 1996; 348:292-5.

28 van Woensel JBM, Wolfs TFW, van Aalderren WMC, Brand PLP, Kimpen JLL. A randomised, double blind, placebo controlled trial of prednisolone in children admitted to hospital with respiratory syncytial virus bronin children admitted to hospital
chiolitis. Thorax 1997;52:634-7.

29 Henry R, Milner AD, Stokes GM, Hodges IG, Groggins RC. Lung function after acute bronchiolitis. Arch Dis Child 1983;58:60-3
30 Webb MS, Henry RL, Milner AD. Oral corticosteroids for wheezing attacks under 18 months. Arch Dis Child 1986;61:15-9.

31 Fox GF, Marsh MJ, Milner AD. Treatment of acute wheezing episodes in infancy with oral salbutamol and prednisolone. Eur $\mathcal{F}$ Pediatr 1996;155: $512-6$.

32 Goodwin A. An uncontrolled assessment of nebulised budesonide in the treatment of acute infantile bronchiolitis. Br f Clin Res 1995;6:113-9.

33 Carlsen KH, Leegaard J, Larsen S, Orstavik I. Nebulised beclomethasone dipropionate in recurrent obstructive episodes after acute bronchiolitis. Arch Dis Child 1988;63:28-33.

34 Reijoner T, Korppi M, Kuikka L, Remes K. Antiinflammatory therapy reduces wheezing after bronchiolitis. Arch Pediatr Adolesc Med 1996;150 $512-7$ 